\title{
Implementasi Prototipe Sila (Social Media Self Development Indonesia) dalam Design Thinking Digital Product Development
}

\author{
Implementation of the Sila Prototype (Social Media Self Development Indonesia) \\ in Design Thinking Digital Product Development
}

\author{
Syamsu Yoga M a'arief*1, Agatha Putra Y Yudhapurnomo ${ }^{2}$, Siti Fatimah ${ }^{3}$, Ressi \\ Okta Wiharifin ${ }^{4}$ \\ ${ }^{1,2,3}$ Sistem Informasi; ${ }^{4}$ Teknik Informatika; Universitas PGRI Madiun \\ 1, 2, ,43 Madiun, Indonesia \\ *1 Syamsuyoga8@gmail.com, 22agatpurnomo@gmail.com, \\ Sitifatim021@gmail.com , ${ }^{4}$ ressyfiokta18@gmail.com
}

\begin{abstract}
Abstrak - Pengembangan diri merupakan hal penting untuk menjadi pribadi yang produktif di era berkembangnya teknologi. pengembangan diri menjadi potensi dan kesiapan diri, yang harus dimiliki oleh setiap manusia dalam menghadapi perkembangan teknologi komunikasi. "SILA" Sosial Media Self Development Indonesia merupakan aplikasi pengembangan diri berbasis sosial yang dikhususkan untuk generasi muda di Indonesia. Implementasi pendekatan Design thinking dengan tahap Emphatize, Define, Ideate, Prototyping, dan Testing menghasilkan konsep sosial media pengembangan diri dimana pengguna dapat melakukan Publish karya sendiri, bergabung di komunitas yang memiliki concern yang sama, saling memberikan motivasi terhadap karya orang lain dengan Fitur yang terdiri dari Upload Foto \& Video, Pemberian Caption, menambah pertemanan, pemberian komentar, dan dapat mengkomersilkan karya. Hasil uji kemenarikan desain user interface SILA dari hasil penerapan sketch, wireframe, dan desain UX UI SILA mendapatkan prosentase 64,7\% setuju, dan 35,3\% sangat setuju bahwa user interface Sila menarik
\end{abstract}

Kata kunci - Design thinking, Media sosial, Prototyping, SILA, Usability, Wireframing.

\begin{abstract}
Self-development is important to become a productive person in the era of technolsogical development. Self-development becomes self-potential and self-readiness, which must be possessed by every human being in facing the development of communication technology. "SILA" Social Media Self Development Indonesia is a social-based self-development application specifically for the younger generation in Indonesia. The implementation of the Design thinking approach with the Emphatize, Define, Ideate, Prototyping, and Testing stages produces a self-development social media concept where users can publish their own work, join communities that have the same concern, motivate each other for the work of others with features consisting from Uploading Photos \& Videos, Giving Captions, adding friends, giving comments, and being able to commercialize the work. The results of the attractiveness test of the SILA user interface design from the results of applying the sketch, wireframe, and UX UI design SILA get a percentage of 64.7\% agree, and $35.3 \%$ strongly agree that the Sila user interface is attractive.
\end{abstract}

Keywords - Design thinking, Prototyping, SILA, Social Media, Usability, Wireframing.

\section{PENDAHULUAN}

Indonesia merupakan negara berkembang dengan jumlah populasi penduduk yang cukup besar mencapai angka 270,20 juta per september 2020 (Badan Pusat Statistik 2020). Untuk saat ini penduduk Indonesia didominasi oleh kelompok usia muda dan produktif, dimana berdasarakan data dari BPS per september 2020 kelompok Generasi Millenial mencapai angka 25,87\%, dan Generasi Z mencapai angka 27,94\% dari jumlah total populasi di Indonesia. Adapun karakteristik dari Generasi Millenial dan Z berkarakter sosial, berbasis teknologi, dan didukung dengan adanya sumber daya internet [1]. Angka tersebut cukup besar dan tentunya dengan banyaknya populasi yang besar di kelompok usia muda dan produktif diharapkan dapat menjadi ujung tombak membawa perubahan besar dan mampu menjawab berbagai permasalahan yang ada di di Indonesia [2].

Namun faktanya saat ini banyak kalangan muda yang salah dalam menggunakan dan memanfaatkan teknologi, akibatnya mereka memiliki sifat individu, tidak peduli terhadap keadaan sosial dan hanya peduli untuk membanggakan pola hidup kebebasan, hedonisme, memiliki visi yang tidak realistis dan terlalu idealistis, yang penting bisa gaya. Generasi millenial belum banyak yang sadar akan 
peluang bagus di depan mereka. Tidak hanya itu, banyak dari generasi muda yang terpengaruh dan meniru budaya asing dan berbudaya liberal [3].

Pengembangan diri merupakan hal penting untuk menjadi pribadi yang produktif di era berkembangnya teknologi. pengembangan diri menjadi potensi dan kesiapan diri, yang harus dimiliki oleh setiap manusia dalam menghadapi perkembangan teknologi komunikasi [4].

Namun pengembangan diri yang dilakukan pada umumnya hanya memanfaatkan pengembangan diri yang terfokus pada lingkungan pendidikan di sekolah, kampus, ataupun bimbingan belajar, atau sebuah komunitas belajar, dan bahkan ada yang tidak tahu harus mulai perubahan dari mana jika ingin melakukan pengembangan diri, jika adapun seseorang akan kebingungan memilih mentor ataupun guru untuk mengajarkan berbagi pengalaman tentang proses pengembangan diri.

Sehingga dari permasalahan diatas ditawarkan sebuah solusi pembuatan "SILA" Sosial Media Self Development Indonesia merupakan aplikasi pengembangan diri berbasis sosial yang dikhususkan untuk generasi muda di Indonesia. Berbeda dengan pembuatan aplikasi pengembangan diri yang selainnya yang hanya terfokus pada pengembangan diri secara personal, aplikasi ini dikembangkan secara khusus dikembangkan dengan konsep media sosial memanfaatkan karakteristik generasi $\mathrm{X}$ dan $\mathrm{Y}$ yang mana memiliki keunggulan berbasis sosial dan menggunakan pendekatan user experience agar lebih dapaat terbentuk teknologi yang lebih humanis.[5]

Harapan dan tujuan dari adanya "SILA" Sosial Media Self Development Indonesia adalah membantu meningkatkan kesadaran pentingnya untuk melakukan pengembangan diri di era perkembangan teknologi dan informasi yang begitu cepat. Sehingga diharapkan pengguna bisa merasa lebih produktif dan dapat terbentuknya "Smart Society" dalam rangka menyongsong era society 5.0 serta membentuk karakter pemuda bangsa yang positif, produktif, dan prestasi.

\section{LANDASAN TEORI}

\section{Generasi Muda di Indonesia}

Generasi muda di Indonesia di dominasi oleh Generasi Y dan Z, Di mana Generasi milenial juga disebut sebagai generasi Y. Salah satu ciri masyarakat milenial adalah peningkatan penggunaan dan keakraban dengan komunikasi, media, dan teknologi digital. Karena dibesarkan oleh kemajuan teknologi, generasi milenial memiliki ciri-ciri kreatif, informatif, mempunyai passion dan produktif [6]. Dan Generasi Z karakteristiknya sama dengan generasi $\mathrm{Y}$ hanya memiliki penambahan Internet dalam kesehariannya [1].

Banyak para pemuda yang mayoritas minim kesadaran dan kontribusi terhadap segala bentuk permasalahan yang ada di Indonesia, padahal mereka merupakan ujung tombak dari bangsa. kesadaran untuk berkontribusi terhadap perubahan hanya dimiliki kelompok minoritas dikalangan tertentu. Banyak pemuda indonesia yang terjebak kultur/budaya liberal dan hedonisme, dimana memilih untuk memanfaatkan usia mudanya untuk lebih banyak bersenang-senang [2].

Terlebih Saat ini banyak kalangan muda yang salah dalam menggunakan dan memanfaatkan teknologi, akibatnya mereka memiliki sifat individu, tidak peduli terhadap keadaan sosial dan hanya peduli untuk membanggakan pola hidup kebebasan, hedonisme, memiliki visi yang tidak realistis dan terlalu idealistis, yang penting bisa gaya. Generasi millenial belum banyak yang sadar akan peluang bagus di depan mereka,. Tidak hanya itu, banyak dari generasi muda yang terpengaruh dan meniru budaya asing [3].

Belum lagi gaya hidup generasi muda yang terbiasa berperilaku konsumtif di mana internet sudah sangat melekat dalam kesehearian, sehingga tidak hanya digunakan untuk komunikasi atau mengkonsumsi konten, melainkan juga segala jenis transaksi, dari transportasi, membeli makanan, jalan-jalan, hingga berbelanja pakaian dan kebutuhan seharihari [7].

\section{Pengembangan Diri}

Pengembangan diri merupakan sebuah proses yang dilakukan oleh manusia untuk membentuk dan mengembangkan potensi diri manusia berdasarkan menggunakan pendidikan, membangun jaringan sosial dan pengalaman hidup.

Perkembangan teknologi komunikasi dapat mengelompokkan manusia pada dua posisi, yakni pembina teknologi atau konsumen teknologi. Penyesuaian diri pada posisi sebagai konsumen dapat menghantarkan kita kepada mudah dan praktis dalam melakukan komunikasi, seperti manfaat internet, manfaat smartphone, televisi dansebagainya. Perkembangan teknologi komunikasi merupakan suatu perkembangan global yang tidak bisa dibendungi atau diantisipasi. Manusia perlu melakukan 
penysuaian diri terhadap perkembangan teknologi, supaya dapat memahaminya [4].

\section{Design Thinking}

Metode "design thinking", metode ini dikenal sebagai suatu proses berpikir komprehensif yang berkonsentrasi untuk menciptakan solusi yang diawali dengan proses empati terhadap suatu kebutuhan tertentu yang berpusat pada manusia (human centered) menuju suatu inovasi berkelanjutan berdasarkan kebutuhan penggunanya. Lebih lanjut lagi dipaparkan bahwa, awalnya terdapat 3 tahapan yang terdiri dari inspiration yaitu kebutuhan atau masalah yang memotivasi pencarian suatu solusi atau inovasi, ideation yaitu proses menghasilkan gagasan, pengembangan dan pengujian gagasan, dan yang terakhir implementation yaitu finalisasi peneranan ke pengguna. Dalam perkembangannya, ketiga tahapan tersebut berkembang menjadi 5 tahapan (empathize, define, ideate, prototype dan test) yang pada dasarnya tidak berbeda jauh namun terdapat penekanan pada bagian tertentu sehingga menghasilkan prosedur yang lebih terperinci [8].

\section{Mobile Application}

Secara umum aplikasi mobile (mobile application) adalah sebuah program aplikasi yang berjalan pada perangkat mobile misalnya smartphone maupun tablet PC yang dirancang untuk menunjang aktivitas pengguna sehingga dapat mempermudah dan meningkatkan fleksibilitas pengguna. [8].

\section{User Experience}

Menurut definisi dari ISO 9241-210, User Experience adalah persepsi dan tanggapan seseorang yang dihasilkan dari suatu produk dan sistem yang melibatkan pengguna. Sebuah prinsip dalam merancang UX adalah untuk mendapatkan nilai kenyamanan dan kepuasan pengguna, Untuk mencapai pengalaman pengguna yang berkualitas tinggi, dapat menerapkan penawaran dari berbagai layanan yang dilakukan seperti teknik pemasaran dan desain antarmuka [9][10].

Pada perancangan sistem informasi atau aplikasi, rancangan user experience (UX) merupakan hal yang penting sebelum akhirnya membuat rancangan antarmuka (User interface, UI). Seringkali dua istilah ini dipadupadankan menjadi UI/UX, yang mengacu pada usaha untuk merancang bagaimana pengguna berinteraksi dengan sistem [11][12].

\section{METODE}

Untuk pengumpulan data digunakan metode observasi dan interview, dan dalam pembuatan produk baru dalam bentuk prototipe maka digunakan metode design thinking dari Stanford Design School (Stanford d.school).[13][14][15]

\section{Design Thinking: A 5 Stage Process}

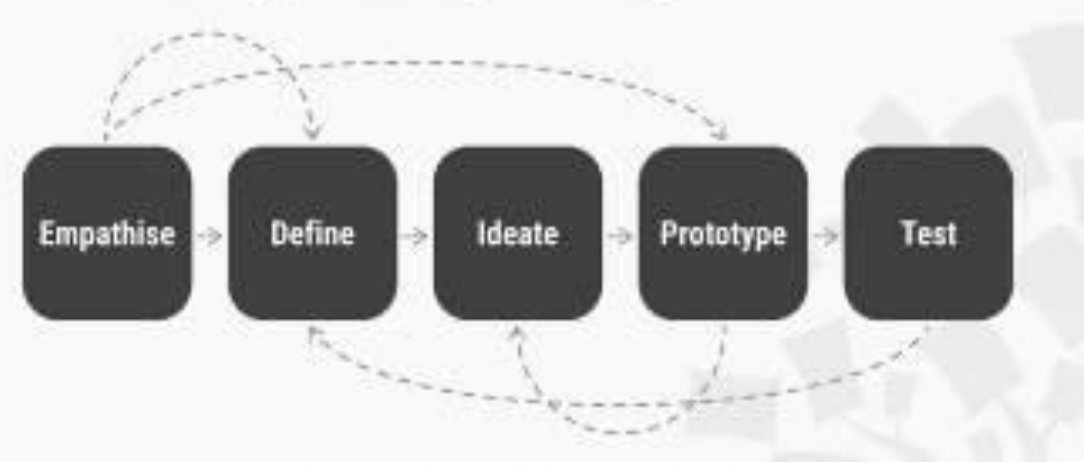

Gambar 1. Alur Pelaksanaan kegiatan.

\section{Emphatize (Empati)}

Pada tahap ini yang dilakukan proses perancangan yang berpusat pada manusia (human centered design), metode ini berupaya untuk memahami pengguna dalam konteks produk yang dirancang, dengan melakukan observasi, wawancara, dan menggabungkan observasi dan wawancara dengan terlebih dahulu diberikan suatu skenario.

Define (Penetapan)

Terdapat kegiatan proses menganalisis dan memahami berbagai wawasan yang telah diperoleh melalui empati, dengan tujuan untuk menentukan pernyataan masalah sebagai point of view atau perhatian utama pada penelitian. 


\section{Ideate (Ide)}

Merupakan proses transisi dari rumusan masalah menuju penyelesaian masalah, adapun dalam proses ideate ini akan berkonsentrasi untuk menghasilkan gagasan atau ide sebagai landasan dalam membuat prototipe rancangan yang akan dibuat.

\section{Prototype (Prototipe)}

Dikenal sebagai rancangan awal suatu produk yang akan dibuat, untuk mendeteksi kesalahan sejak dini dan memperoleh berbagai kemungkinan baru. Dalam penerapannya, rancangan awal yang dibuat akan diujicoba kepada pengguna untuk memperoleh respon dan feedback yang sesuai untuk menyempurnakan rancangan.

\section{Tahapan Test (Uji coba) atau pengujian}

Tahapan ini dilakukan untuk mengumpulkan berbagai feedback pengguna dari berbagai rancangan akhir yang telah dirumuskan dalam proses prototipe sebelumnya. Proses ini merupakan tahap akhir namun bersifat life cycle sehingga memungkinkan perulangan dan kembali pada tahap perancangan sebelumnya apabila terdapat kesalahan.

\section{HASIL DAN PEMBAHASAN}

\section{Emphatize (Empati)}

Pada tahap ini dilakukan pendekatan dengan melakukan Interview kepada 15 responden, yang mana responden terdiri dari berbagai macam lintas umur dengan kualifikasi pendidikan SMP, SMA, dan pendidikan tinggi. Interview dilakukan dengan menitikberatkan apa yang menjadi keresahan responden selama menggunakan media sosial, dan bagaimana anggapan mereka tentang bentuk, kriteria, dan harapan dari sebuah media sosial yang positif. Dari hasil interview dan pengisian kuisioner secara garis besar kriteria sosial media yang posisif adalah sosial media yang memiliki konten edukasi dan motivasi, media hiburan serta wawasan, juga mudah penggunaannya.

\section{Define (Penetapan)}

Setelah mendapatkan data dan informasi mengenai ekspektasi gambaran sosial media yang baik, selanjutnya dilakukan penetapan dengan mengadakan diskusi oleh tim sila mengenai bentuk "SILA" social media Self Development Indonesia, adapun hasil diskusi tersebut menghasilkan sebuah rumusan masalah berupa : "Bagaimana membuat Sebuah Sosial Media yang memiliki konten positif dalam konteks Self Development ?"

Ideate (Ide)
Pada tahap ini dilakukan proses pencarian Ide, dimana seluruh tim berhak untuk mengemukakan idenya, yang kemudian dilakukan analisa terhadap keseluruhan ide yang ada. Selain memanfaatkan data dari hasil wawancara, dilakukan observasi mengenai sosial media yang memiliki banyak pemakai. Observasi dilakukan dengan pengamatan langsung terhadap sosial media yang biasa dipakai oleh tim SILA, kemudian dibandingkan dengan data HOOTSUITE 2021. Dimana Youtube, WhtasApp, Instagram, dan Facebook menempati 4 besar sosial media yang banyak dipakai.

Berdasarkan hasil dari obeservasi dan pemaparan masing ide tim sila, didapat sebuah ide produk dimana "Konsep Sila (Sosial Media Self Development Indonesia) Bisa dijadikan tempat Pengembangan diri \& berapresiasi dengan cara melakukan Publish karya sendiri, bergabung di komunitas yang memiliki concern yang sama, saling memberikan motivasi terhadap karya orang lain."

Fitur yang terdapat pada Sila (Social Media Self Development Indonesia), terdiri dari Upload Foto \& Video, Pemberian Caption, menambah pertemanan, pemberian komentar, dan dapat mengkomersilkan karya.

\section{Prototype (Prototipe)}

\section{A. Sketch Prototyping}

Untuk pembuatan prototipe dilakukan dengan pembuatan Sketch Prototyping dan Digital Prototyping. dimana kegiatan ini berfungsi untuk membuat gambaran aplikasi SILA, dalam bentuk gambaran di atas kertas. Sebelum ditindaklanjuti ke proses Digital Protyping. [16][17]

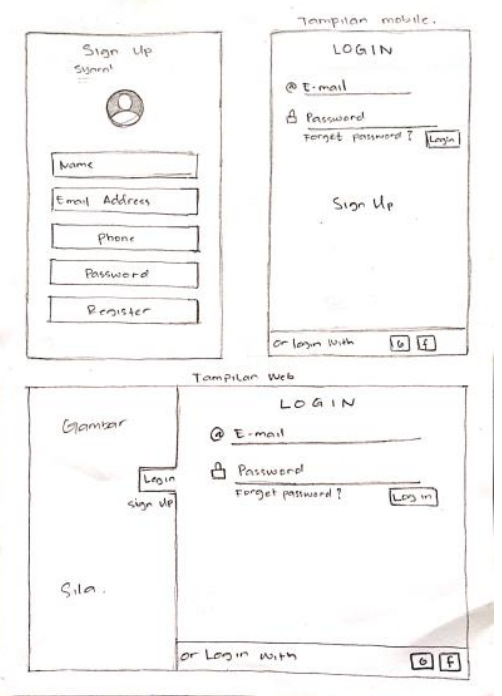

Gambar 2. Sketch Halaman Login 


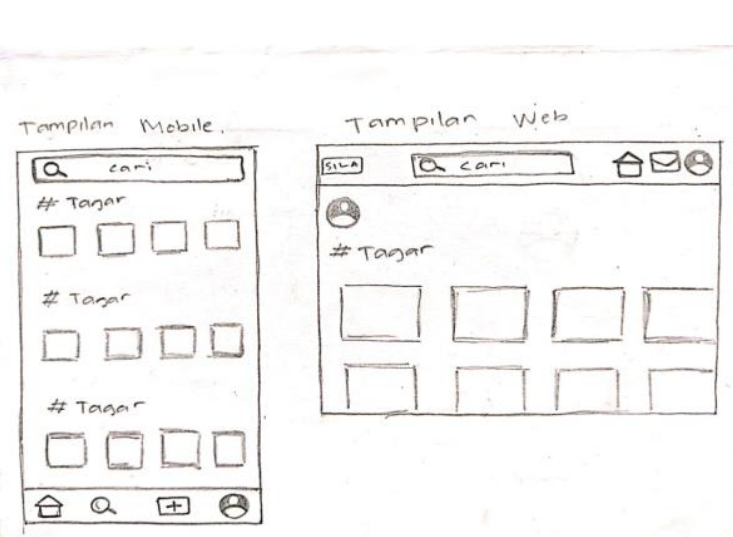

Gambar 3. Sketch Halaman Pencarian
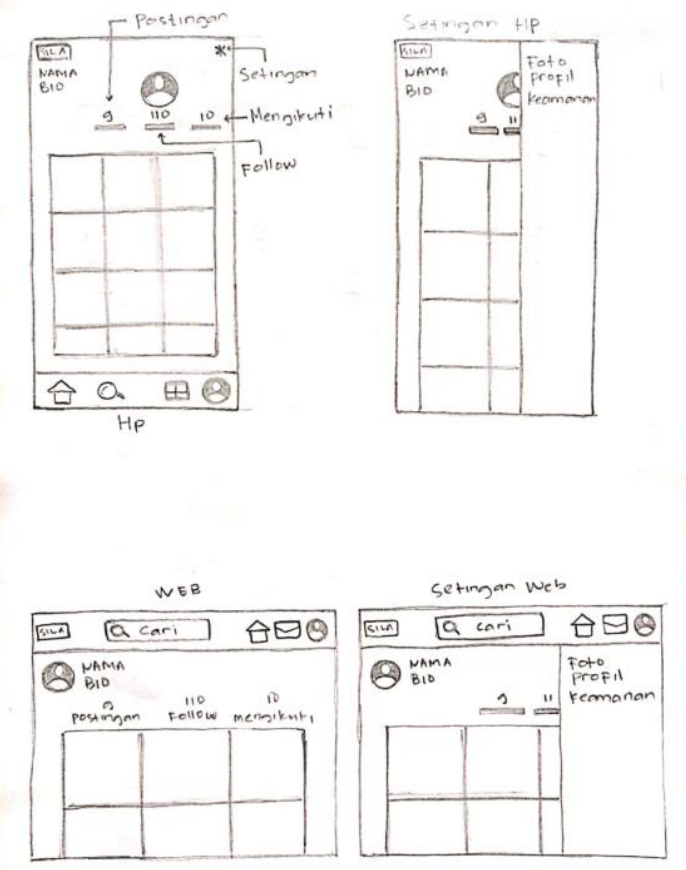

Gambar 4. Sketch Halaman profil
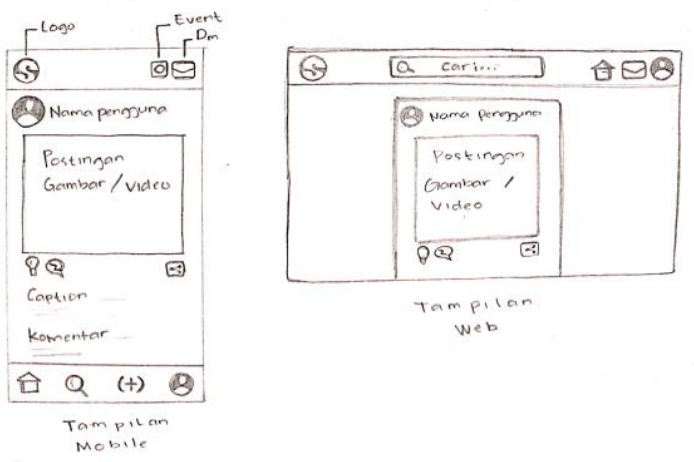

Tampilan

Gambar 5. Sketch Halaman Beranda

\section{B. Digital Prototyping}

Untuk pembuatan prototipe dilakukan dengan pembuatan Sketch Prototyping dan Digital Prototyping. dimana kegiatan ini berfungsi untuk membuat gambaran aplikasi SILA, dalam bentuk gambaran di atas kertas. Sebelum ditindaklanjuti ke proses Digital Protyping. [18]

\section{Wireframe}

Untuk pembuatan prototipe dilakukan dengan pembuatan Sketch Prototyping dan Digital Prototyping. dimana kegiatan ini berfungsi untuk membuat gambaran aplikasi SILA, dalam bentuk gambaran di atas kertas. Sebelum ditindaklanjuti ke proses Digital Protyping.

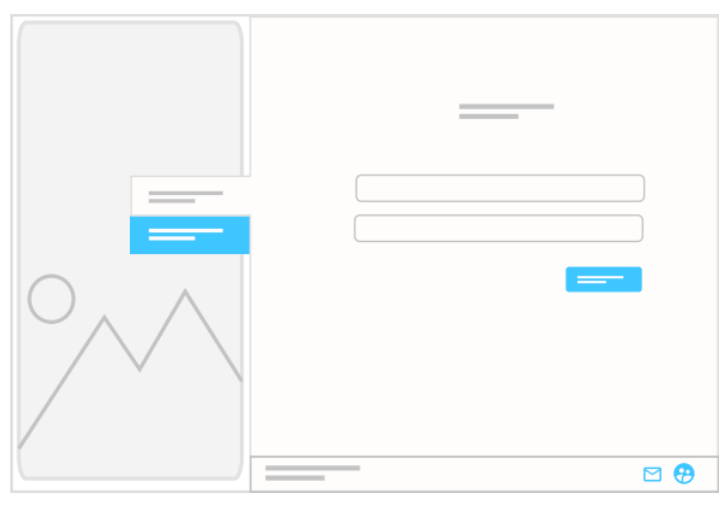

Gambar 6. Wireframe Halaman Login

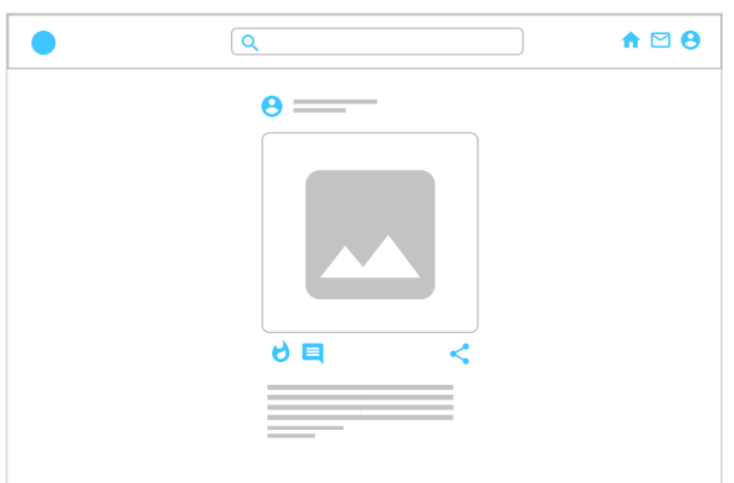

Gambar 7. Wireframe Halaman Beranda

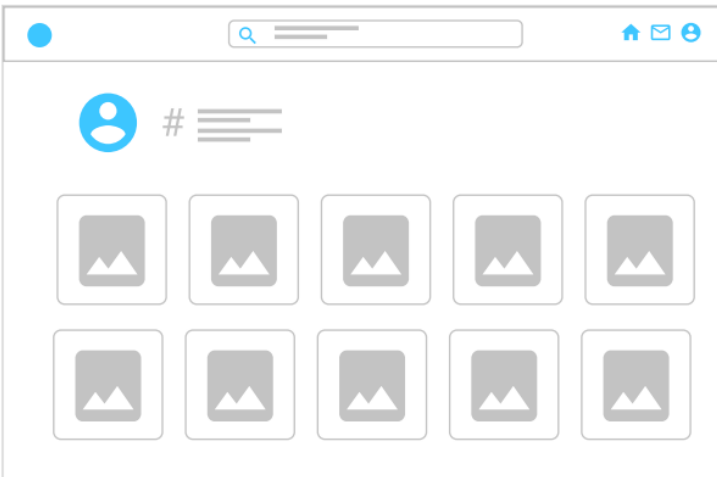

Gambar 8. Wireframe Halaman Pencarian 


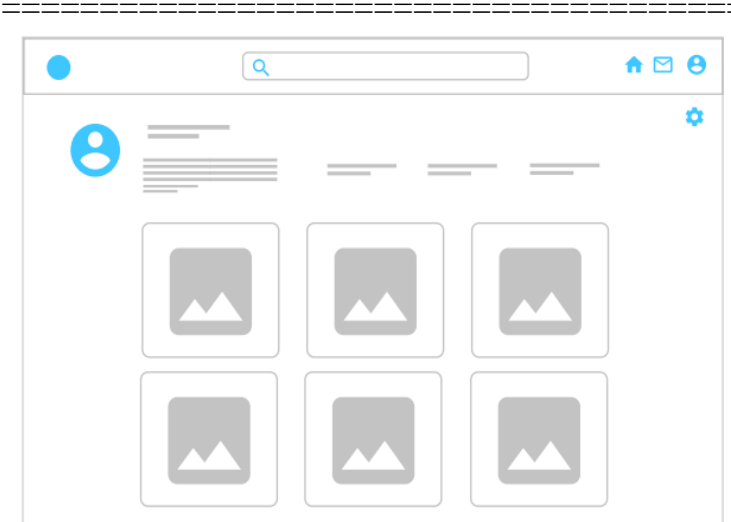

Gambar 9. Wireframe Halaman Profil

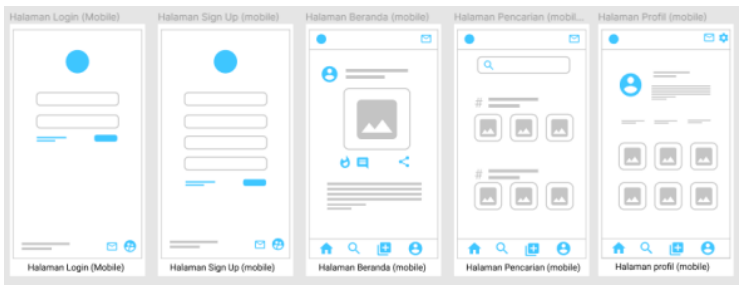

Gambar 10. Wireframe Versi Mobile

\section{$U X \&$ UI Prototype}

Pada tahap ini dilakukan pembuatan desain User interface, serta desain User Experiene versi dekstop dan Web [19]. Berikut adalah hasilnya.
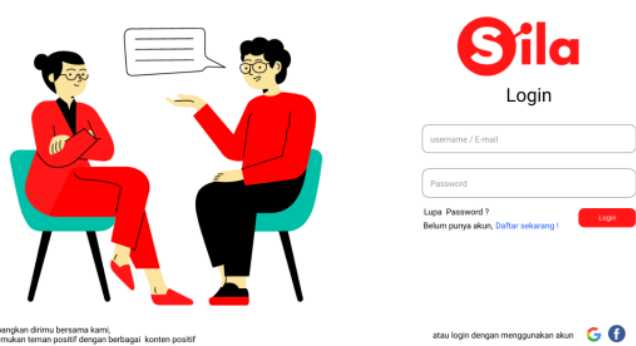

Gambar 11. UX \&UI Halaman Login
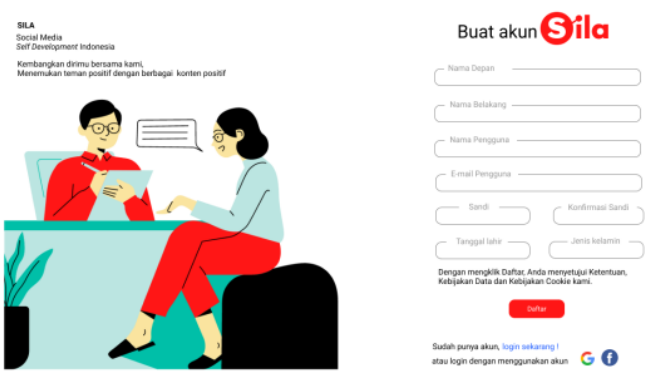

Gambar 12. UX \&UI Halaman Daftar

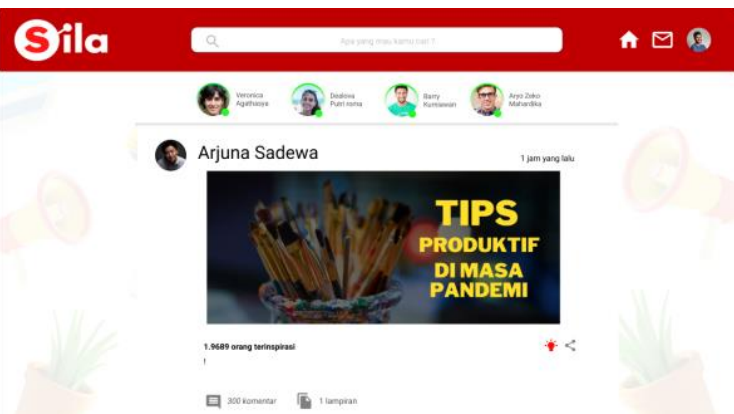

Gambar 13. UX \&UI Halaman Beranda

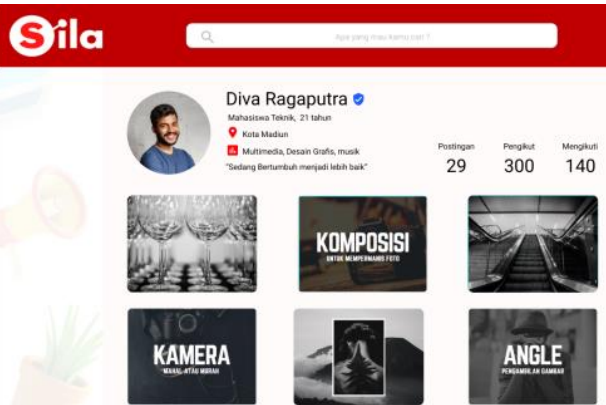

Gambar 14. UX \&UI Halaman Profil
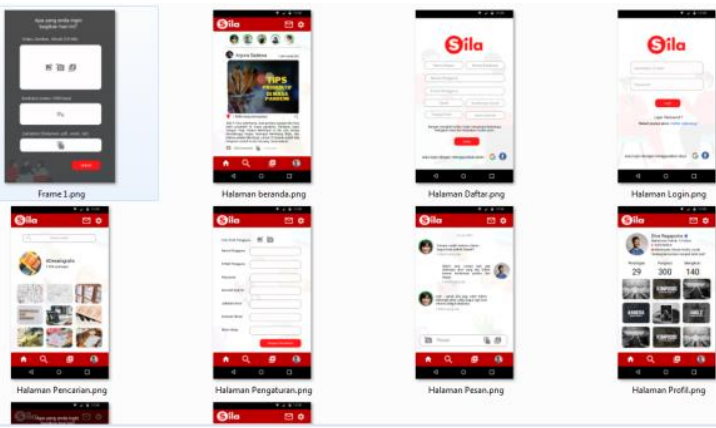

Gambar 15. UX \&UI Versi Mobile

\section{Tahapan Test (Uji Coba) / Pengujian}

\section{A. Usability Test}

Usability test dilakukan pada tahap sketching \& wireframing, untuk menguji apakah ada yang perlu ditambahkan terkait produk yang sudah dibuat.

Pengujian ini menggunakan 10 orang responden yang terdiri dari 5 ahli media dan 5 orang kontributor SILA. Menurut Nielsen Pengambilan minimal 5 responden diambil dikarenakan sudah cukup mewakili konsep atau ide yang perlu ditambahkan terhadap produk SILA.[20] Dari hasil tes usability didapat bahwa perlu adanya penambahan file attachment pada bagian posting.

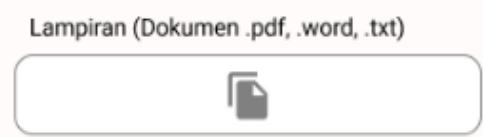

Gambar 16. Penambahan Attachment 
Merubah konsep suka yang semulanya menggunakan simbol love, menjadi simbol lampu yang menandakan postingan yang dipasang dapat memberi inspirasi. Kedua hal tersebut menjadi pembeda dari sosial media yang sudah pernah ada sebelumnya.

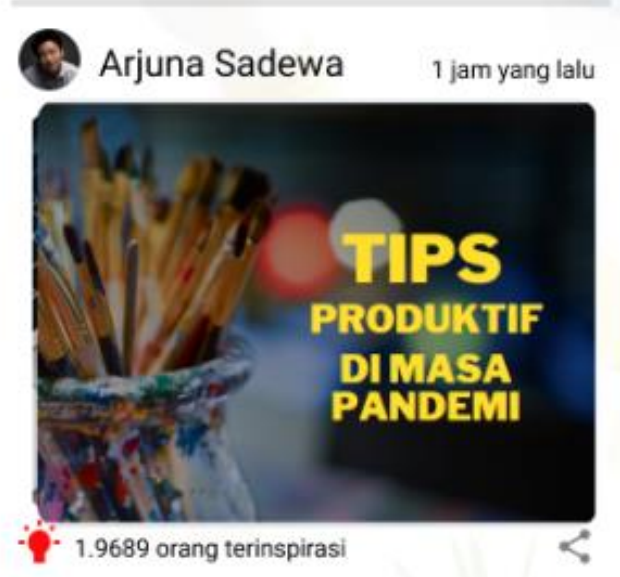

Ada 5 Tips sederhana, soal gimana supaya kita bisa lebih produktif di masa pandemi. Pertama wajib bangun Pagi, Kedua Membuat to Do List, ketiga Berolahraga ringan, keempat Membaca Buku, dan kelima adalah Membuat Jurnal. Di bawah sudah ada lampiran contoh to do list yang biasa kubuat.

300 komentar

Gambar 17. Perubahan tombol suka menjadi inspirasi \& penambahan file unduh lampiran

\section{B. Kemenarikan User Interface}

Pada tahap ini dilakukan pengujian kemenarikan user interface. Dengan memberikan lima pertanyaan berupa kuisioner kepada 17 responden. Berkaitan dengan bentuk visuali dari user interface SILA. Adapun pertanyaannya adalah

Tabel. 1 Daftar pertanyaan uji kemenarikan tampilan sistem

\begin{tabular}{lll}
\hline No & Pertanyaan \\
\hline 1 & $\begin{array}{l}\text { Pemilihan jenis font dan ukuran font } \\
\text { pada sistem nyaman untuk dilihat }\end{array}$ \\
\hline 2 & $\begin{array}{l}\text { Pemilihan ilustrasi menarik untuk } \\
\text { dilihat }\end{array}$ \\
\hline 3 & $\begin{array}{l}\text { Pemilihan Palette warna menarik untuk } \\
\text { dilihat }\end{array}$ \\
\hline 4 & $\begin{array}{l}\text { Peletakan Komposisi elemen } \\
\text { multimedia nyaman untuk dilihat }\end{array}$ \\
\hline 5 & $\begin{array}{l}\text { Secara keseluruhan tampilan dari sistem } \\
\text { menarik untuk dilihat }\end{array}$ \\
\hline
\end{tabular}
hasilnya :
Dari sebaran kuisioner, berikut adalah

Pemilihan jenis font dan ukuran font pada sistem nyaman untuk dilihat

17 jawaban

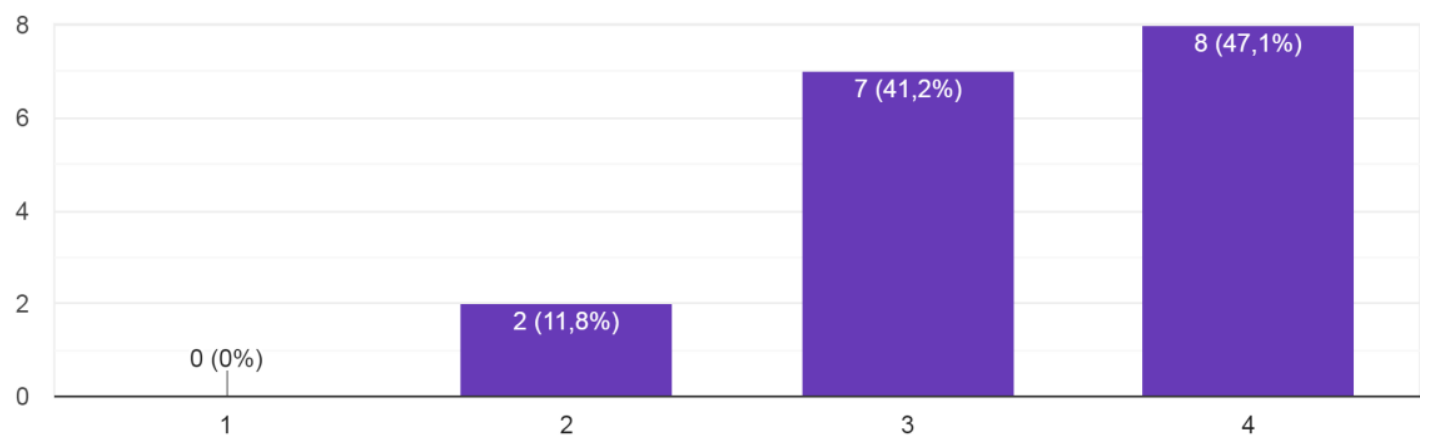


Pemilihan ilustrasi gambar pada sistem menarik untuk dilihat

17 jawaban

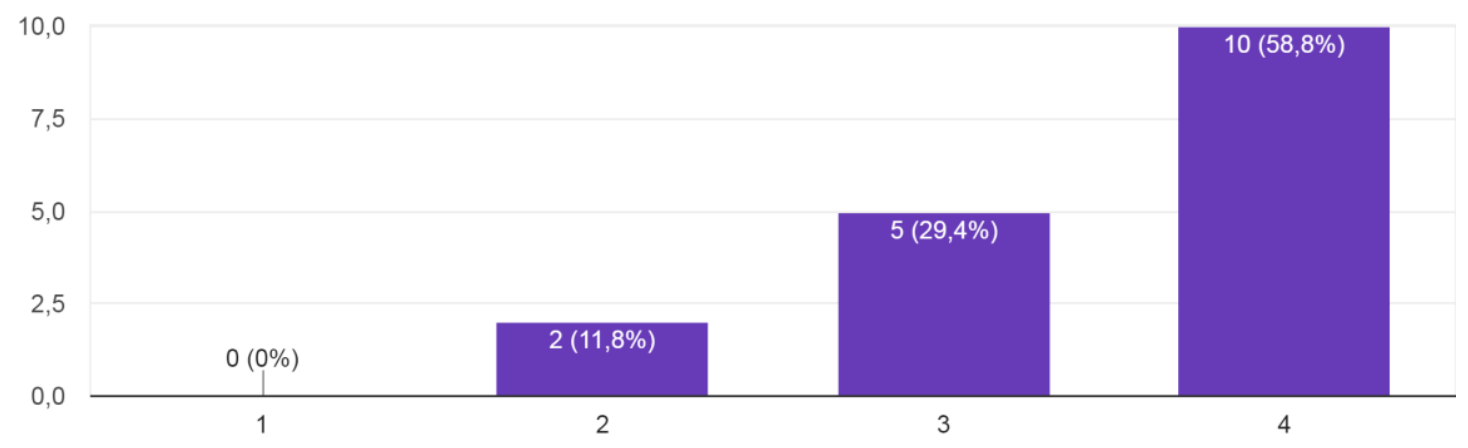

Pemilihan Pallete warna pada sistem menarik untuk dilihat

17 jawaban

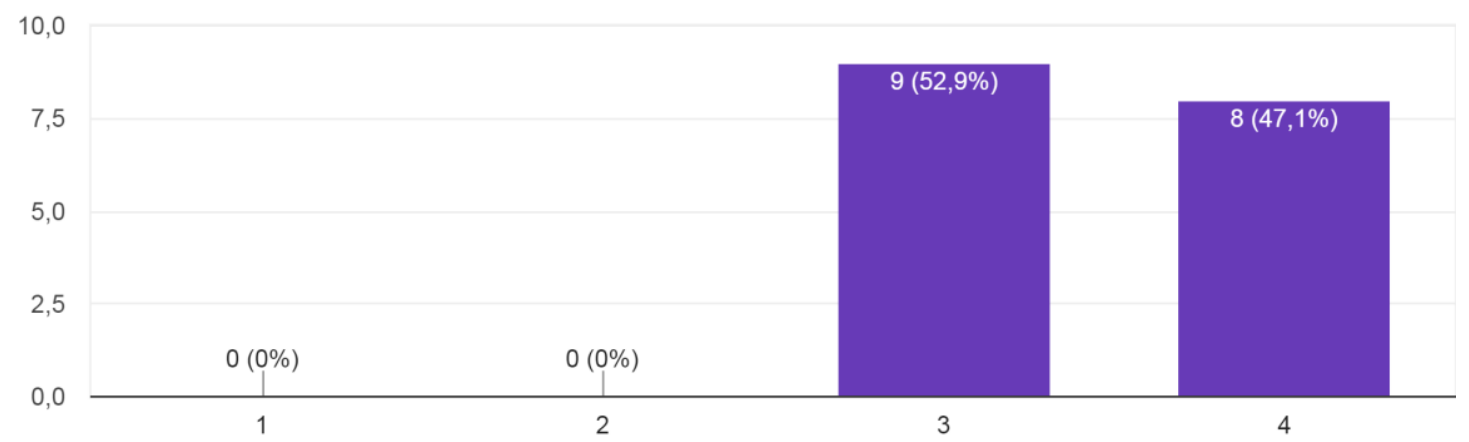

Penempatan layout dan komposisi elemen multimedia (teks, gambar, foto, Animasi dan video) sudah sesuai, dan nyaman untuk dilihat.

17 jawaban

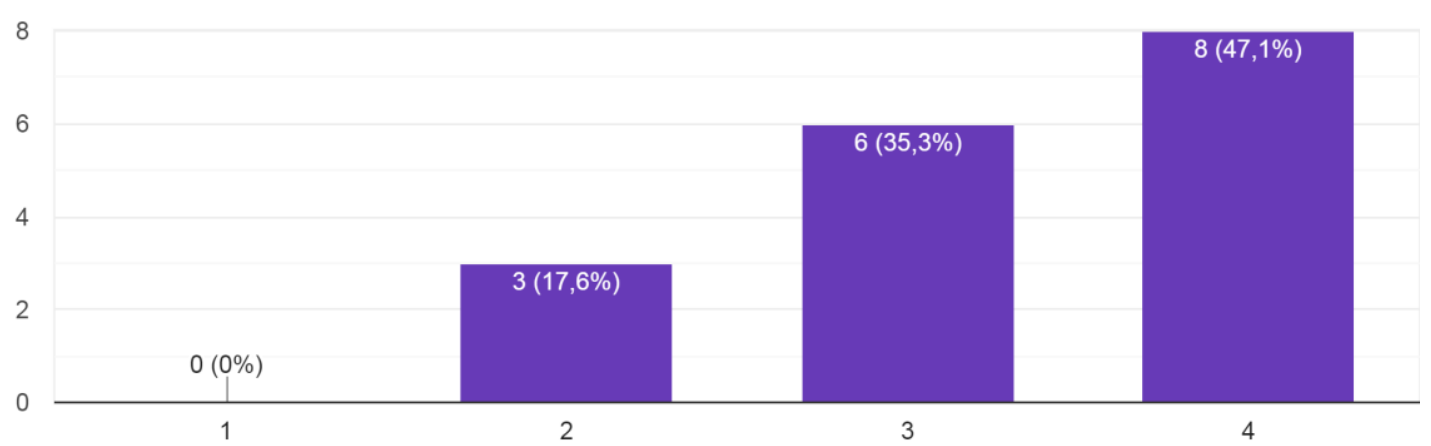




\section{Secara keseluruhan tampilan user interface sistem menarik \\ 17 jawaban}

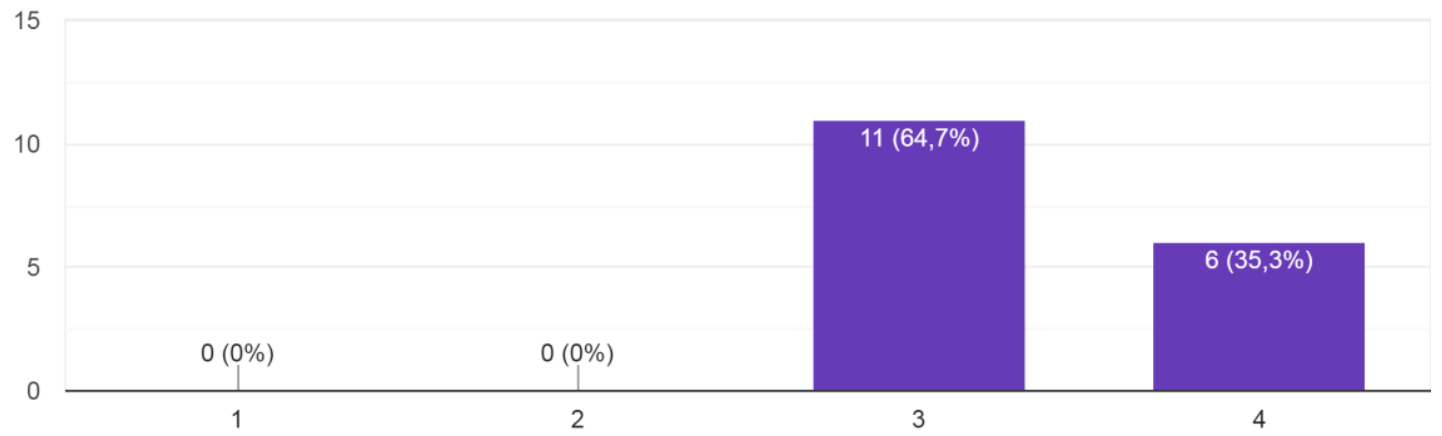

Gambar 18. Hasil sebaran kuisioner uji kemenarikan user interface SILA.

Secara keseluruhan kemenarikan desain user interface SILA mendapatkan prosentase $64,7 \%$ setuju, dan $35,3 \%$ sangat setuju bahwa user interface Sila menarik. Namun ada perlu perbaikan terkait beberapa hal seperti perlu adanya versi night mode untuk pengguna smartphone, pengaturan size font di bagian halaman profil, dan masih ada hal yang menjadi masukan untuk perbaikan selanjutnya.

\section{KESIMPULAN}

Pembuatan prototipe SILA (Social media Self Development Indonesia) menggunakan pendekatan Sketching, wireframe, dan UX UI menghasilkan prosentase $64,7 \%$ setuju, dan $35,3 \%$ sangat setuju bahwa user interface Sila menarik. Untuk saran dan masukan dari responden perlu perbaikan terkait beberapa hal seperti perlu adanya versi night mode untuk pengguna smartphone, pengaturan size font di bagian halaman profil, dan masih ada hal yang menjadi masukan untuk perbaikan selanjutnya.

\section{DAFTAR PUSTAKA}

[1] I. Gunawan and H. Argadinata, "Dampak pembelajaran berkarakter terhadap penguatan karakter siswa generasi milenial," $J A M P$, vol. 3, no. 2019, pp. 160-170, 2020.

[2] S. Zuhri, "PENTINGNYA BUDAYA LITERASI MEDIA DAN AKTUALISASI BELA NEGARA GENERASI MILENIAL," PUBLIC Adm. J. Res., vol. 2, no. 4, pp. 393405, 2020.

[3] U. Hasanah, "IMPLEMENTASI NILAINILAI PANCASILA DI KALANGAN GENERASI MILLENIAL UNTUK MEMBENDUNG DIRI DARI DAMPAK
NEGATIF REVOLUSI INDUSTRI 4.0," PEDAGOGY, vol. 8, no. 1, pp. 52-59, 2021.

[4] M. Aminullah and M. Ali, "PERKEMBANGAN TEKNOLOGI KOMUNIKASI ERA 4 . 0," Komunike, vol. 7, no. 1, pp. 1-23, 2020.

[5] D. Setiawan and M. Lenawati, "Peran dan Strategi Perguruan Tinggi dalam Menghadapi Era Society 5.0," Res. Comput. Inf. Syst. Technol. Manag., vol. 3, no. 1, p. 1, 2020.

[6] H. Sazali, F. Rozi, P. Edward, and T. Hall, "Belanja Online dan Jebakan Budaya Hidup Digital pada Masyarakat Milenial Online Shopping and Digital Living Culture Traps in Millennial Communities," SIMBOLIKA, vol. 6 , no. 2, 2020.

[7] J. P. Malahayati et al., "Peran kecerdasan budaya dan kepribadian terhadap perilaku konsumtif online generasi milenial yang merantau di jakarta," Psikol. Malahayati, vol. 2, no. 2, pp. 57-71, 2020.

[8] A. A. Razi, I. R. Mutiaz, and P. Setiawan, "Penerapan Metode Design Thinking Pada Model Perancangan Ui/Ux Aplikasi Penanganan Laporan Kehilangan Dan Temuan Barang Tercecer," Desain Komun. Vis. Manaj. Desain dan Periklanan, vol. 3, no. 2, p. 219, 2018.

[9] A. R. Setiadi, "Perancangan UI / UX menggunakan pendekatan HCD ( HumanCentered design ) pada website Thriftdoor," AUTOMATA, vol. 1, no. 2, 2020.

[10] D. Setiawan and S. L. Wicaksono, "Evaluasi Usability Google Classroom Menggunakan System Usability Scale," vol. 2, no. 1, pp. 71-78, 2020.

[11] P. Utomo, "Pendekatan Object Oriented UX pada Perancangan Aplikasi Manajemen Order," in Seminar Nasional Sistem 
Informasi dan Teknologi (SISFOTEK) ke 4, 2020, pp. 230-235.

[12] D. Derisma, "The Usability Analysis Online Learning Site for Supporting Computer programming Course Using System Usability Scale (SUS) in a University," Int. J. Interact. Mob. Technol., vol. 14, no. 9, p. $182,2020$.

[13] L. Domingo, D. Moore, D. Sirkin, G. Toye, L. Leifer, and M. Cutkosky, "STRATEGIC PROTOTYPING TO LEARN IN STANFORD UNIVERSITY'S ME310 DESIGN INNOVATION COURSE," Proc. Des. Soc. Des. Conf., vol. 1, pp. 1687-1696, May 2020.

[14] I. Permata Sari and S. Analia Zain, "Implementasi Metode Pendekatan Design Thinking dalam Pembuatan Aplikasi Happy Class Di Kampus UPI Cibiru,” 2020.

[15] G. Reflin, "EVALUASI BISNIS STARTUP SUKA-GRAFIS MENGGUNAKAN PENDEKATAN DESIGN THINKING," 2020.

[16] D. Buschek, C. Anlauff, and F. Lachner, "Paper2Wire - A Case Study of UserCentred Development of Machine Learning Tools for UX Designers," i-com, vol. 20, no. 1, pp. 19-32, Apr. 2021.

[17] J. Li, G. W. Tigwell, and K. Shinohara, "Accessibility of high-fidelity prototyping tools," Conf. Hum. Factors Comput. Syst. Proc., May 2021.

[18] V. P. Sermuga Pandian, S. Suleri, C. Beecks, and M. Jarke, "MetaMorph: AI Assistance to Transform Lo-Fi Sketches to Higher Fidelities," ACM Int. Conf. Proceeding Ser., pp. 403-412, Dec. 2020.

[19] M. A. Muhyidin, M. A. Sulhan, and A. Sevtiana, "PERANCANGAN UI/UX APLIKASI MY CIC LAYANAN INFORMASI AKADEMIK MAHASISWA MENGGUNAKAN APLIKASI FIGMA," $J$. Digit, vol. 10, no. 2, pp. 208-219, Dec. 2020.

[20] M. U. A. Iryanto, W. H. N. Putra, A. Dwi, and Herlambang, "Evaluasi Usability Aplikasi SIAP TARIK Dengan Menggunakan Metode Usability Testing dan System Usability Scale (SUS) Pada Puskesmas Tarik Sidoarjo," J. Pengemb. Teknol. Inf. dan Ilmu Komput., vol. 3, no. 8, pp. 7708-7716, 2019. 